\title{
Raising Funds for ffPS
}

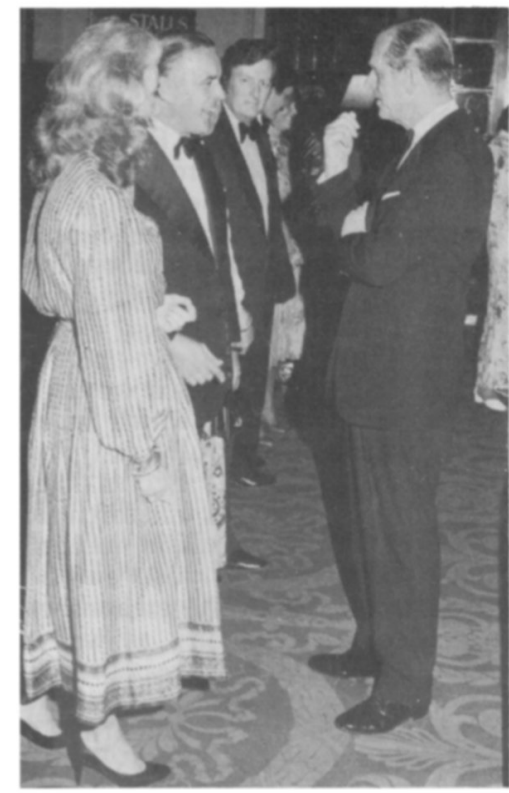

right to left: $\mathrm{HRH}$ The Prince Philip, Duke of Edinburgh, David Jones, $\mathrm{Mr}$ and Mrs Tim Walker

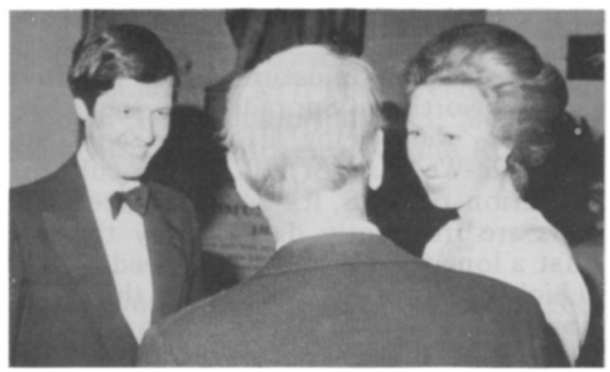

right to left: $\mathrm{HRH}$ The Princess Anne, Mrs Mark Phillips, Sir Peter Scott, Edward Hoare

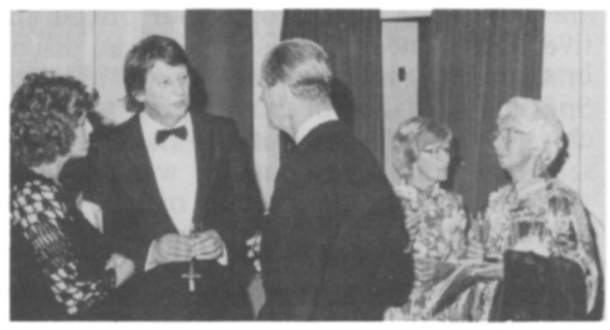

right to left: Maisie Fitter, Lady Scott, HRH The Prince Philip, Duke of Edinburgh, John Gooders, Robbie Chapman

\section{Wild life Gala}

On 19 May 1982, the ffPS joined the International Trust for Nature Conservation for a Wildlife Gala Preview of the Pirates of Penzance at the Theatre Royal, Drury Lane. We were honoured by the presence of HRH Princess Anne, Mrs Mark Phillips, and HRH the Duke of Edinburgh.

The star-studded cast included George Cole as the Major General, Tim Curry as the Pirate King, Pamela Stephenson as Mabel and Annie Ross as Ruth. After a triumph on Broadway, this new production moved to London, and by kind arrangement with Michael White Productions, the two societies were able to arrange this charity gala. Many ff PS members attended and our President, Sir Peter Scott, and Lady Scott, received the Royal Party in the theatre, and accompanied them to the Royal Box. During the interval, the Royal Party was introduced to representatives of both societies, together with some of those responsible for organizing the gala.

The most enjoyable evening raised $£ 2400$ for the two charities. The tremendous success of the evening was largely due to the efforts of the Organizing Committee (whose names appear in the official programme), ably chaired by Lady Craigton. The complicated arrangements leading up to the gala were handled by Helen Saloman. Those who helped are too numerous to be listed, but we would like to say a special thank you to Sean McCarthy and Jeanette Koch and also to Edward Wright, without whom the magnificent Souvenir Programme would not have been possible. Copies of the programme are available from the ffPS office - the cover features a photograph of the monk seals (courtesy of Bruce Coleman Ltd) - price 50p to cover postage. 


\section{The Monk Seal Appeal}

An important population of the Mediterranean monk seal Monachus monachus in the Northern Sporades, in the Aegean Seas, was in danger because local fisheries were being affected (see Oryx, February 1982). When Dr Thomas Schultze-Westrum of IUCN's Ecoculture Task Force brought the problem to the attention of ffPS, its Council agreed to help compensate the fishermen, whose nets are frequently damaged by the seals. At the same time it was recognized that a long term solution was needed, particularly in relation to the factory ships which are probably the main threat to the livelihood of both the fishermen and the seals.

In May this year I visited the area with Gareth Trewartha, a tour operator based in Salonika, with two purposes in mind. The first was to see if it would be possible to arrange an Oryx wildlife tour to northern Greece, which would include a visit to the seals. This objective was achieved successfully and plans are now going ahead for a tour priced about $£ 500$ for 1983 . The second objective was to meet the fishermen and discuss the problems. In this I was fortunate in that Dr Schultze-Westrum was able to join me in Alonissos, in the northern Sporades. He has been studying wildlife in the area for over 15 years and is a close friend of many of the fishermen and together we visited the areas where seals are found. In passing we saw numerous Eleonora's falcons, as well as Andouin's gulls, and a pair of rose-coloured starlings. I was most reassured by the fishermen's sincere concern for the future of the monk seal. At the headquarters of the Fishermen's Cooperative, they are recording all seal sightings to build up a data-base for future conservation efforts. Provided proper controls can be exerted over the large-scale fishing there is every reason to hope that the traditional Kaiki fishing and seals can continue to coexist.

JOHN A. BURTON

\section{Sponsored Birdwatch 1982}

On 19 May an ffPS team, for the second year running, challenged a team from Country Life Magazine to a sponsored birdwatch to beat the record for the number of birds seen on one day. The ffPS team were driving a six-wheel drive Range Rover loaned by Pace Petroleum and the Country Life team were in a Porsche. Our team comprised Bill Oddie, who apart from his TV work, is also a Council member of the RSPB; John Gooders, one of Britain's best known writers of bird books; Cliff Walker, Warden of Walberswick National Nature Reserve and Ron Johns, one of the most experienced birders in Britain. Although an attempt on the British Record was obviously an important part of the day, the most important aspect was sponsorship, and between the two teams over $£ 4000$ was raised for conservation. Last year's event received widespread publicity in newspapers and on radio and TV, and this year Major Steadman directed a film which followed both teams throughout the day. The resulting 50 -minute TV documentary will be shown on British TVs new Channel 4 shortly after it begins transmission. Both teams sought their birds in East Anglia, and strict rules forbade the seeking out of rare nesting birds which might be harmed by such activities. Each team member had to see, or hear, every bird - hearing was allowed to minimize disturbance to the birds. After a hectic and exhausting day, the ffPS team returned to the finishing point just before midnight having broken the previous year's record and clocked up 150 birds in 24 hours. But it was a real 'photo-finish', when, a few minutes later, the Country Life team (David Tomlinson, Country Life; Jeremy Sorenson, RSPB warden; Bill Urwin; and Peter Smith) returned with a score of 151 . However, the main success was the money 
raised and we are grateful to all our sponsors, most of whom sponsored at $£ 1$ per bird, who included: Dragon Films; British Petroleum; Town and Gown Travel; Waterlow (Dunstable); Barbour; Swift Binoculars (Pyser); Pirelli; Haiths Bird Foods; Hayter; Savills; Bedfords; Swaffham, Tradecoaters; Martini; McAlpine Humberoak; Newton and Godin; Shell; Thorntons; Todd Research; and Rudolph Agnew.

\section{ffPS $100 \%$ Fund}

The 100\% Fund helps finance numerous conservation projects all over the world. Donations are always welcomed at the ffPS office; nothing is deducted for administration.

William Collins and Co. Ltd have donated ten copies each of two field guides to ffPS. The books $A$ Field Guide to the Birds of East Africa by J. G. Williams and N. Arlott, and $A$ Field Guide to the Larger Mammals of Africa by Jean Dorst and Pierre Dandelot, will be sent to Sudan, to be used by the Ministry of Wildlife, and the University of Juba, in their wildlife education programmes.

\section{Rescue of a Bullfinch}

ff PS, through the $100 \%$ Fund, has contributed to the creation of a reserve for a bird thought to be almost extinct until 1980. This is the Sao Miguel bullfinch Pyrrhula murina in the Azores, where it inhabits thick laurel forests. A small population was found by Dr Gerald Le Grand, of the University of the Azores, on Pico da Vara. The birds' dependence on the native vegetation - one group was seen feeding exclusively on Laurus azorica buds - means that they are very vulnerable to the recent planting of exotic species in their area, notably Cryptomeria japonica, and the invasion of introduced exotics such as Clethra arborea from Madeira and Pittosporum undulatum from Austria.

\section{New Threat to Grizzlies and Wolves}

The US Forest Service and the Federal Highway Administration want to pave the road along the northwest boundary of Glacier National Park, Montana. This would encourage high speed traffic and increased human activity in an area freely travelled by grizzly bears and wolves. Objectors, including the National Park Service and the Fish and Wildlife Service, say that spot improvements to the dirt road would be sufficient. The Fish and Wildlife Service has issued a jeopardy opinion under the provisions of the Endangered Species Act, but the Highway Administration continues to press for paving the road.

\section{Protection for Great Bustard}

To protect the great bustard Otis tarda in Hungary, where the chief threat is eggs and young being crushed by agricultural machinery on the huge and intensively cultivated plains, 3500 ha have been set aside as a reserve to be cultivated by traditional methods. A rearing station has also been built where eggs and young brought in by agricultural workers can be hatched, reared and released. This is carefully designed so that the young never see the attendants who thus are not imprinted on them. 